\title{
Synthesis, Biological and Anti-tumor Evaluation of Some New Nucleosides Incorporating Heterocyclic Moieties
}

Fekria MA Soliman, Nadia TA Dawoud* and Rehab M Hamza

Department of Chemistry, Faculty of Science (Girls), Al-Azhar University, Nasr City, Cairo, Egypt

\begin{abstract}
1,3-diaryl-1-propen-3-ones 1a-h, were used as building blocks for a large range of nucleoside analogs incorporating five and six-membered heterocyclic rings. Heterocyclic compounds incorporating aromatic moieties (2-11) and their $\mathrm{N}$-nucleoside analogs (13-20) were synthesized. New compounds were evaluated for their potential antimicrobial, antifungal activities and for their in vitro cytotoxic activity against three cell lines: human breast cancer cell line (MCF7), colon carcinoma cells (HCT) and human epidermid/arynx carcinoma cell line (HEp2).
\end{abstract}

Keywords: Chalcones; Heterocyclic compounds; N-Nucleosides; Antimicrobial and anticancer activities

\section{Introduction}

Heterocyclic compounds occur widely in nature. Nitrogencontaining heterocyclic molecules constitute the largest portion of these chemical entities, which are part of many natural products. Indazole derivatives are interesting compounds, with many having biological as well as pharmaceutical activity [1-3]. Some new indazole derivatives were investigated as electronically active materials [49]. Cyanopyridone and cyanopyridine derivatives have promising antimicrobial activities [10,11] as well as anti-cancer activities [1214]. Oxazine derivatives represent an important classes of organic compounds; 1,3-oxazines in particular have been extensively studied because of their profound biological activities including antibacterial $[15,16]$, antifungal [17], antituberculor [18], antitumor and anti-HIV agents $[19,20]$. 1,3-Oxazine derivatives are also known as progesterone receptor agonists [21]. Pyrimidine derivatives are very well known in medicinal chemistry for their therapeutic applications [22,23]. One important class of pyrimidine is 2-thiopyrimidine and its derivatives, which are also well known as 2-mercaptopyrimidine compounds $[24,25]$. Carbohydrates are ubiquitous in nature, readily available, cheap, biodegradable and non-toxic materials [26,27]. Presence of several functional groups and stereogenic centers in carbohydrates permit stereochemical differentiations, enantiopure compound synthesis [2830], use as chiral templates [31], biosensors [32] and as precursors for several biologically active products [33]. Besides these crucial roles, carbohydrates possess a unique set of chemical and structural feature that make them particularly attractive as molecular scaffolds.

The aim of this work was to design, synthesis of indazole, pyridines, 2 -aminooxazines and/or 2-thiopyrimidine derivatives bearing aromatic moieties and use these compounds as a basis for the synthesis of a series of nucleosides. Some of the new compounds were then examined for cytotoxic activity via assays on human breast cancer cell line MCF-7, colon carcinoma cells (HCT), human epidermid/arynx carcinoma cell line (HEp2).

\section{Experimental}

All melting points for the prepared derivatives were measured in capillary tubes using a Gallen-Kamp apparatus and were uncorrected. The IR spectra were recorded on a Perkin-Elmer 1650 spectrophotometer (KBr pellets) and the wave numbers were given in $\mathrm{cm}-1$. The $1 \mathrm{H}, 13 \mathrm{C}$ NMR spectra were measured in dimethyl sulphoxide-d6 as a solvent using a Varian Gemini 180 spectrometer operating at $300 \mathrm{MHz}$ for $1 \mathrm{H}$, and $75 \mathrm{MHz}$ for $13 \mathrm{C}$. TMS was used as an internal standard and the chemical shifts were reported as $\delta \mathrm{ppm}$. The FAB mass spectra were recorded on a JEOL SX 102/DA-6000 mass spectrometer.
Synthesis of N-(4-(5-(4-methoxyphenyl)-4,5-dihydro-1Hpyrazol-3-yl)phenyl)benzamide (2)

A mixture of (E)-N-(4-(3-(4'-methoxyphenyl) acryloyl) phenyl) benzamide $(1 \mathrm{~h})(0.01 \mathrm{~mol})$ and hydrazine hydrate $(0.01 \mathrm{~mol})$ in $30 \mathrm{ml}$ of ethanol was refluxed for $6 \mathrm{~h}$. The yellow precipitate formed after cooling was filtered off, dried and recrystallized from ethanol to afford the required product (2) as yellow crystals, in $75 \%$ yield, m.p. $181^{\circ} \mathrm{C}$; Requires: C, 74.39; H, 5.66; N, 11.32; Found: C, 74.35; H, 5.7; N, 11.4. IR ( $\left.\mathrm{cm}^{-1}\right): 3340,2942,2846,1650,1600,1510$.

Synthesis of ethyl 6-(4-chlorophenyl)-2-oxo-4-phenylcyclohex-3-ene carboxylate (3)

A mixture of (1f) $(0.01 \mathrm{~mol})$ and ethylacetoacetate $(0.01 \mathrm{~mol})$ in $30 \mathrm{ml}$ of absolute ethanol containing sodium ethoxide (prepared from $0.2 \mathrm{~g}$ of sodium metal and $4.6 \mathrm{ml}$ of absolute ethanol) was refluxed for $6 \mathrm{~h}$. After concentration and cooling the residue was poured into water, filtered off, washed well with dilute alcohol and recrystallized from ethanol to afford 3 as white crystals, in $60 \%$ yield, m.p $124^{\circ} \mathrm{C}$. Requires: C, 71.08; H, 5.35; Cl, 10.01: Found: C, 71.1; H, 5.4; Cl, 10.1. IR $\left(\mathrm{cm}^{-1}\right)$ : 3006, 2928, 2818, 1698, 1660. MS ( $\left.\mathrm{m} / \mathrm{z}, \%\right) ; 355(9.2 \%), 320$ (3.8\%), 308 (6.1\%), 278 (34.6\%), 249(1.6\%), 192 (4.8\%), 144 (100\%).

Synthesis of 4-(4-chlorophenyl)-6-phenyl-3,3a,4,5-tetrahydro-2H-indazolone (4)

A mixture of $3(0.01 \mathrm{~mol})$ and hydrazine hydrate $(0.01 \mathrm{~mol})$ in $15 \mathrm{ml}$ of acetic acid was heated under reflux for $6 \mathrm{~h}$. The solvent was evaporated and the product was collected, washed well with dilute ethanol and recrystallized from ethanol to give (4) as brown crystals, in $60 \%$ yield, m.p $144^{\circ} \mathrm{C}$. Requires: C, $70.69 ; \mathrm{H}, 4.65 ; \mathrm{N}, 8.68 ; \mathrm{Cl}$, 11.007: Found: C, 71.0; H, 4.7; N, 8.7; Cl, $11.1 \mathrm{IR}\left(\mathrm{cm}^{-1}\right)$ : 3392, 3216; 2918, 2846, 1670, 1604, 1508. MS (m/z, \%); $\mathrm{M}^{+}, \mathrm{M}^{+2}, \mathrm{M}^{+3}, 322,324$, $325(99.4,30.7,4.6 \%)$.

*Corresponding author: Nadia TA Dawoud, Department of Chemistry Faculty of Science (Girls), Al-Azhar University, Nasr City, Cairo, Egypt, Tel: 021144771184/021144771184; E-mail: dawoudnadia@yahoo.com

Received October 02, 2015; Accepted November 11, 2015; Published November 17,2015

Citation: Soliman FMA, Dawoud NTA, Hamza RM (2015) Synthesis, Biological and Anti-tumor Evaluation of Some New Nucleosides Incorporating Heterocyclic Moieties. Med chem 5: 496-504. doi: 10.4172/2161-0444.1000308

Copyright: (C) 2015 Soliman FMA, et al. This is an open-access article distributed under the terms of the Creative Commons Attribution License, which permits unrestricted use, distribution, and reproduction in any medium, provided the original author and source are credited. 


\section{Synthesis of 4,6-diaryl-2-oxo-1,2-dihydropyridine-3-carbo-} nitrile (5a-c)

A mixture of $1 \mathrm{c}, 1 \mathrm{f}$, and $1 \mathrm{~g}(0.01 \mathrm{~mol})$, ethylcyanoacetate $(0.01 \mathrm{~mol})$ and ammonium acetate $(0.04 \mathrm{~mol})$ in $30 \mathrm{ml}$ of absolute ethanol was heated under reflux for $6 \mathrm{~h}$. It was then allowed to cool, filtered off, washed well with water, then with dilute alcohol, and recrystallized from ethanol to give the corresponding derivatives (5a-c) respectively.

5a as yellow crystals, in $70 \%$ yield, m.p. $51^{\circ} \mathrm{C}$. Requires: C, 67.75; H, 3.86; N, 8.32; Cl, 10.54: Found C, 67.6; H, 3.9; N, 8.4; Cl, 10.2; MS $(\mathrm{m} / \mathrm{z}, \%) ; 336.3(96.0 \%) \mathrm{M}^{+}, 50(100 \%) .{ }^{1} \mathrm{H}-\mathrm{NMR}$ spectrum $\left(\mathrm{DMSO}-\mathrm{d}_{6}\right): \delta 3.83\left(\mathrm{~s}, 3 \mathrm{H}, \mathrm{OCH}_{3}\right), 7.12-8.10(\mathrm{~m}, 8 \mathrm{H}, \mathrm{C}=\mathrm{CH}$ and $\mathrm{Ar}-\mathrm{H})$ $8.28(\mathrm{~s}, 1 \mathrm{H}, \mathrm{NH})$.

$5 \mathrm{~b}$ as white crystals, in $70 \%$ yield, m.p. $80^{\circ} \mathrm{C}$. Requires: C, 70.47 ; H, 3.58; N, 9.13; Cl, 11.58: Found C, 70.5; H, 3.6; N, 9.2; Cl, 11.6; IR $\left(\mathrm{cm}^{-1}\right)$ : 3460-3230, 2230-2210, 1654-1662.

$5 \mathrm{c}$ as brown crystals, in $75 \%$ yield, m.p. $60^{\circ} \mathrm{C}$. Requires: C, 64.75 ; H, 3.03; N, 9.44; Cl, 11.97: Found: C, 64.5; H, 3.00; N, 9.5; Cl, 11.5; IR ( $\left.\mathrm{cm}^{-1}\right)$ : 3460-3230, 2230-2210, 1654-1662.

\section{Synthesis of 2-imino-4,6-diaryl-1,2-dihydropyridin-3-carbo-} nitrile (6a-c)

A mixture of $1 \mathrm{c}, 1 \mathrm{f}$, and $1 \mathrm{~g}(0.01 \mathrm{~mol})$, malononitrile $(0.01 \mathrm{~mol})$ and ammonium acetate $(0.04 \mathrm{~mol})$ was fused on a sand-bath at $135-165$ ${ }^{\circ} \mathrm{C}$ for $3 \mathrm{~h}$. The product formed after cooling was washed with water, then with dilute ethanol, and recrystallized from the proper solvent to give (6a-c) respectively.

$6 \mathrm{a}$ as white crystals, in $71 \%$ yield, m.p. $52^{\circ} \mathrm{C}$. Requires: C, 67.95 ; $\mathrm{H}, 4.17$; N, 12.51; Cl, 10.58: Found: $\mathrm{C}, 68.0 ; \mathrm{H}, 4.2 ; \mathrm{N}, 9.5 ; \mathrm{Cl}, 12.5$; $\mathrm{Cl}, 10.6$; IR $\left(\mathrm{cm}^{-1}\right): 3100,2220,1662,690(\mathrm{C}-\mathrm{Cl})$.

$6 \mathrm{~b}$ as white crystals, in $70 \%$ yield, m.p. $75^{\circ} \mathrm{C}$. Requires: C, 70.70 ; 3.92; N, 13.74; Cl, 11.62: Found: C, 70.7; H, 3.9; N, 13.8; Cl, 11.6; IR $\left(\mathrm{cm}^{-1}\right): 3366,2212,1626,686(\mathrm{C}-\mathrm{Cl})$.

6c as black crystals in $60 \%$ yield, m.p. $70^{\circ} \mathrm{C}$. Requires: C, 64.67 ; 3.38; N, 14.21; Cl, 12.01: Found: C, 65.0; H, 3.4; N, 4.1; Cl, 12.1; IR $\left(\mathrm{cm}^{-1}\right): 3114,2208,1648,640(\mathrm{C}-\mathrm{Cl})$.

\section{Synthesis of 4,6-diaryl-2-thioxo-1,2-dihydropyridin-3-carbo-} nitrile derivatives $(7 \mathbf{a}, \mathbf{b})$

A mixture of $5 \mathrm{a}$ and/or $5 \mathrm{c}(0.01 \mathrm{~mol})$ and P2S5 $(0.01 \mathrm{~mol})$ in 15 $\mathrm{ml}$ of dry xylene was refluxed for $6 \mathrm{~h}$. After cooling the solvent was evaporated under reduced pressure and the product was treated with petroleum ether (b.p. $40-60^{\circ} \mathrm{C}$ ), then recrystallized from the proper solvent as $7 \mathrm{a}, \mathrm{b}$.

$7 \mathrm{a}$ as reddish brown crystals, in $70 \%$ yield, m.p. $200^{\circ} \mathrm{C}$. Requires: C, 64.68; H, 3.68; N, 7.94; S, 9.07; Cl, 10.07: Found: C, 64.7; H, 3.7; N, 7.9; S, 9.1; Cl, 10.1; IR ( $\left.\mathrm{cm}^{-1}\right): 3354,3437,1590,1588,1218,1212$. MS m/z, (\%): 352.5 (9.82\%), 324.2 (9.57\%), 270 (10.18\%), 241.2 (9.1\%, 207.2 (10.55\%), 171.2 (9.38\%), 63 (100\%).

$7 \mathrm{~b}$ as dark brown crystals, in $60 \%$ yield, m.p. $110-112^{\circ} \mathrm{C}$. Requires: C, 61.44; H, 2.88; N, 8.96; S, 10.24; Cl, 11.36: Found: C, 61.5; H, 2.9; N, 8.8; S, 10.2; Cl, 11.4; IR ( $\left(\mathrm{cm}^{-1}\right): 3354,3437,1590,1588,1218,1212$.

Synthesis of 6-(4-chlorophenyl)-4-(4-methoxyph-enyl)2-oxo-1,2-dihydropyridin-3-carboxamide (8)

A mixture of $(5 \mathrm{a})(1 \mathrm{~g})$ of and $(5 \mathrm{ml})$ of $30-40 \% \mathrm{H}_{2} \mathrm{SO}_{4}$ in $15 \mathrm{ml}$ acetic acid was refluxed for $6 \mathrm{~h}$. The Precipitate was filtered off and recrystallized from benzene to give (8) as white crystals in $60 \%$ yield, m.p $120^{\circ} \mathrm{C}$. Requires: C, $67.35 ; \mathrm{H}, 4.43 ; \mathrm{N}, 8.27 ; \mathrm{Cl}, 10.48$ : Found: C, 67.1; H, 4.1; N, 8.1; Cl, 10.23; IR ( $\left.\mathrm{cm}^{-1}\right): 3410,3464,1648$.

Synthesis of 6-(4-chlorophenyl)-4-(4-methoxyph-enyl)2-oxo-1,2-dihydropyridine-3-carboxylic acid (9)

A mixture of (5a) $(0.2 \mathrm{~mol})$, ethyl alcohol $(13 \mathrm{ml})$ and $(3 \mathrm{ml})$ of $25 \% \mathrm{NaOH}$ was stirred on magnetic stirrer, $(10 \mathrm{ml})$ of $30 \% \mathrm{H}_{2} \mathrm{O}_{2}$ was added gradually, the solution left to cool in ice bath. After an hour, the reaction was permitted to run at $50^{\circ} \mathrm{C}$ for an additional $3 \mathrm{~h}$. Then $5 \%$ sulphuric acid was added to neutralize the solution, the solvent was evaporated and solid product was recrystallized from benzene to give 9 as white crystals in $60 \%$ yield, m.p. $170^{\circ} \mathrm{C}$. Requires: $67.16 ; \mathrm{H}, 4.12$; $\mathrm{N}, 4.12 ; \mathrm{Cl}, 10.45$ : Found: C, 67.1; H, 4.1; N, 4.1; Cl, 10.23; IR $\left(\mathrm{cm}^{-1}\right)$ : $3433,3200,1686,1590$.

Synthesis 4,6-diaryl-5,6-dihydropyrimidin-2(1H)-thione derivatives $(10 \mathrm{a}-\mathrm{e})$

A mixture of (1a, b, f, g and h) $(0.01 \mathrm{~mol})$ and thiourea $(0.01 \mathrm{~mol})$ in $30 \mathrm{ml}$ ethanol containing $(0.01 \mathrm{~mol})$ sodium ethoxide was heated under reflux for $6 \mathrm{~h}$. After concentration and cooling, the residue was diluted with water, filtered off, then washed well with warm water and dilute alcohol and recrystallised from the proper solvent to give (10a-e).

$10 \mathrm{a}$ as pale white crystals in $70 \%$ yield, m.p. $200^{\circ} \mathrm{C}$. Requires: C, 50.59; H, 3.16; N, 7.37; S, 8.43; Cl, 9.35; Br, 21.08: Found: C, 50.6; H, 3.2; N, 7.4; S, 8.4; Cl, 9.4; Br, 21.1; IR $\left(\mathrm{cm}^{-1}\right): 3408,3156,2620,1662$, $1014,454,580$ (C-Br, C-Cl).

$10 \mathrm{~b}$ as brown crystals in $70 \%$ yield, m.p. $190^{\circ} \mathrm{C}$. Requires: C, 57.31; H, 3.58; N, 8.35; S, 9.55; Cl, 21.19; Found: C, 57.3; H, 3.6; $\mathrm{N}, 8.4 ; \mathrm{S}, 9.6 ; \mathrm{Cl}, 21.2 ; \mathrm{IR}\left(\mathrm{cm}^{-1}\right): 3398,3152,2620,1656,1018,580$ (C-Cl).

$10 \mathrm{c}$ as yellow crystals in $70 \%$ yield, m.p. $135^{\circ} \mathrm{C}$. Requires: C, 55.65; H, 3.76; N, 8.11; S, 9.27; Br, 23.18; Found: C, 55.7; H, 3.8; N, 8.2; S, 9.3; Br, 23.3; IR ( $\left.\mathrm{cm}^{-1}\right): 3325,3150,2620,1650,1018,580$ (C-Cl).

$10 \mathrm{~d}$ as dark brown crystals in $60 \%$ yield, m.p. $215^{\circ} \mathrm{C}$. Requires: C, 57.83; H, 3.78; N, 8.63; S, 11.01; Cl, 12.22; Found: C, 57.9; H, 3.9; N, 9.7; S, 11.1; Cl, 12.3; IR $\left(\mathrm{cm}^{-1}\right): 3210,3140,2706,1650,1012,620$ (C-Cl).

$10 \mathrm{e}$ as yellow crystals in $60 \%$ yield, m.p. $131^{\circ} \mathrm{C}$. Requires: C, 69.39; H,5.06; N,10.1;S,7.71; Found: C, 69.4; H, 5.1; N, 10.2; S, 7.8; IR $\left(\mathrm{cm}^{-1}\right): 3258,1650,1026$.

\section{Synthesis of 2-amino-4,6-diaryl-2H-1,3-oxazine derivatives} (11a-c)

A mixture of $1 \mathrm{~d}, \mathrm{f}, \mathrm{h}(0.01 \mathrm{~mol})$ and urea $(0.01 \mathrm{~mol})$ in $15 \mathrm{ml}$ of absolute ethanol containing $6 \mathrm{ml}$ of glacial acetic acid was heated under reflux for $6 \mathrm{~h}$. The precipitate that formed after cooling was collected, washed well with dilute ethanol and recrystallized from the proper solvent to give $11 \mathrm{a}-\mathrm{c}$, respectively.

11a as Brown crystals in $60 \%$ yield, m.p. $194^{\circ} \mathrm{C}$. Requires: C, 67.01; H, 5.23; N, 9.77; Cl, 12.39; Found C, 67.1; H, 5.3; N, 9.8;Cl, 12.4; IR $\left(\mathrm{cm}^{-1}\right): 3348,1652,1210,516$.

$11 \mathrm{~b}$ as white crystals in $70 \%$ yield, m.p. $109^{\circ} \mathrm{C}$. Requires: C, 67.48; H, 4.56; N, 9.84; Cl, 12.47; Found: C, 67.5; H, 4.6; N, 9.9; Cl, 12.5; IR (cm $\left.{ }^{-1}\right): 3200,1654,1212,686 .{ }^{1} \mathrm{H}-\mathrm{NMR}$ (DMSO-d6): $\delta 2.1(\mathrm{~s}, 2 \mathrm{H}$, $\mathrm{NH} 2), 3.81,3.82$ (d, 1H, CHa), 6.9, $7.02(\mathrm{~d}, 1 \mathrm{H}, \mathrm{CHb}), 7.5-8.1(\mathrm{~m}, 9 \mathrm{H}$, Ar-H). 13C-NMR: $\delta 37.2$ (C1), 161.1 (C2), 97.07 (C3), 168.8 (C4), 
130.5 (C5), 127.7 (C6), 139.3 (C7), 143.4 (C8), 134.5 (C9), 127.3 (C10), $143.1\left(\mathrm{C}^{`}\right), 129.6\left(\mathrm{C}^{`}\right), 131.8\left(\mathrm{C}^{`}\right), 128.3\left(\mathrm{C}^{`}\right), 127.7\left(\mathrm{C} 2^{\prime}\right)$, $119.4\left(\mathrm{C}^{\prime}\right)$.

$11 \mathrm{c}$ as white crystals in $60 \%$ yield, m.p. $210^{\circ} \mathrm{C}$. Requires: $\mathrm{C}, 72.18$; H, 5.26; N, 10.52; Found: C, 72.2; H, 5.3; N, 10.6; IR $\left(\mathrm{cm}^{-1}\right): 3286$, 1662,1260 .

\section{Synthesis of nucleoside derivatives (13)}

A suspension of $2(0.01 \mathrm{~mol})$ in $6 \mathrm{ml}$ of aqueous potassium hydroxide (prepared by dissolving $0.01 \mathrm{~mol}$ in $6 \mathrm{ml}$ of distilled water) was stirred by using a magnetic stirrer for $3 \mathrm{~h}$, then a solution of 12 $(0.0 \mathrm{~mol})$ dissolved in $30 \mathrm{ml}$ of dry acetone was added drop-wise while stirring which continued for $12 \mathrm{~h}$. After evaporation of the solvent (reduced pressure), the residue was washed with dilute ethanol several times and the precipitate formed was recrystallised from ethanol to give 13 as brown crystals in $60 \%$ yield, m.p. $168^{\circ} \mathrm{C}$. Requires: C, $64.92 ; \mathrm{H}$, 5.41; N, 7.32; Found: C, 65.0; H, 5.4; N, 7.2. IR $\left(\mathrm{cm}^{-1}\right): 3346.2,3000.9$, 2840.3, 1663.6, 1600.1. 1H-NMR (DMSO-d6): $\delta 6.9,7.0$ (d, H-1' and H-2'), 2.41, 2.43 (s, 3H, 2xCOCH 3 ), $10.04-10.52$ (s, 1H, 2xOH).

Synthesis of (2R,3S,4R,5S)-5-hydroxy-2-[3-oxo-(4-phenyl5-(2-chloro-phenyl)-3,3a,4,5-tetrahydro-2H-indazol-2-yl) tetrahydro-2H-pyran-3,4-diyl diacetate (14)

A suspension of $4(0.01 \mathrm{~mol})$ in $6 \mathrm{ml}$ of aqueous potassium hydroxide (prepared by dissolving $0.01 \mathrm{~mol}$ in $6 \mathrm{ml}$ of distilled water) was stirred using a magnetic stirrer for $3 \mathrm{~h}$, then a solution of $12(0.01$ mol) dissolved in $30 \mathrm{ml}$ of dry acetone was added drop-wise while stirring, which continued for $12 \mathrm{~h}$. After evaporation of the solvent (reduced pressure), the residue left was washed with dilute ethanol (several times) and the precipitate formed was re-crystallized from ethanol to give 14 as grey crystals, in $60 \%$ yield, m.p. $102^{\circ} \mathrm{C}$. Requires: C, 62.51; H, 4.83; N, 5.21; Cl, 6.60; Found: C, 62.5; H, 4.8; N, 5.3; Cl, 6.7; IR $\left(\mathrm{cm}^{-1}\right)$ : 3443, 1742, 1606 and 1376.

\section{Synthesis of nucleoside derivatives 15 and 16}

A suspension of the cyanopyridone derivatives $5 \mathrm{c}$ and/or 2-iminocyanopyridine $6 \mathrm{c}(0.01 \mathrm{~mol})$ in $6 \mathrm{ml}$ of aqueous $\mathrm{KOH}$ solution (prepared from dissolving $(0.01 \mathrm{~mol})$ solid $\mathrm{KOH}$ in $6 \mathrm{ml}$ of distilled water) was well stirred (magnetic stirrer) at room temperature for $3 \mathrm{~h}$, then a solution of $12(0.01 \mathrm{~mol})$ dissolved in $30 \mathrm{ml}$ of dry acetone was added drop-wise while stirring. Stirring was continued for further $12 \mathrm{~h}$. After evaporation of the excess solvent (reduced pressure), the residue left was washed with dilute alcohol (several times) and the precipitate formed was recrystallized from ethanol to give 15 and 16 .

15 as brown crystals, in $70 \%$ yield, m.p. $70^{\circ} \mathrm{C}$. Requires: C, 56.55; H, 4.34; N, 5.28; Cl, 6.69; Found: C, 56.6; H, 4.5; N, 5.4; Cl, 7.1; IR $\left(\mathrm{cm}^{-1}\right): 3315.4,1648,1595,525.8(\mathrm{C}-\mathrm{Cl}) .{ }^{1} \mathrm{H}-\mathrm{NMR}\left(\mathrm{DMSO}_{6} \mathrm{~d}_{6}\right): \delta$ 4.41 (s, 1H, NH), 6.68-7.90 (m, 7H, Ar-H), 8.05 (d, 2H, 2xCH), 8.07(s, $1 \mathrm{H}, \mathrm{OH}), 3.3,3.41,3.44\left(\mathrm{t}, 2 \mathrm{H}, \mathrm{CH}_{2}\right), 8.07\left(\mathrm{~s}, 1 \mathrm{H}, \mathrm{NH}_{2}\right) . \mathrm{MS}(\mathrm{m} / z$, \%): 497.45 (1.1\%) M+ 461 (1.05\%), 232 (15.4\%), 190 (1.09\%), 148 $(1.37 \%)$.

16 as black crystals in $60 \%$ yield, m.p. $76^{\circ} \mathrm{C}$. Requires: C, $56.65 ; \mathrm{H}$, 4.53; N, 7.93; Cl, 6.7; Found: C, 56.87; H, 4.67; N, 8.1; Cl, 6.9; IR $\left(\mathrm{cm}^{-1}\right)$ : 3314 (br), 1655, 1584, 526 (C-Cl). ${ }^{1} \mathrm{H}-\mathrm{NMR}$ (DMSO-d $\mathrm{d}_{6}$ : $\delta 1.97,2.49$ (s, $\left.3 \mathrm{H}, 2 \mathrm{xCOCH}_{3}\right), 6.55(\mathrm{~s}, 1 \mathrm{H}, \mathrm{NH}), 2.44,3.44(\mathrm{~d}, 2 \mathrm{H}, 2 \mathrm{xCH}), 6.82-7.94$ $(\mathrm{m}, 7 \mathrm{H}, \mathrm{Ar}-\mathrm{H}), 8.12\left(\mathrm{~s}, 2 \mathrm{H}, \mathrm{NH}_{2}\right), 9.75(\mathrm{~s}, 1 \mathrm{H}, \mathrm{OH})$. MS $(\mathrm{m} / z, 511.5$ (0.4\%), $484.5(0.4 \%), 473.5(0.69 \%), 426(0.45 \%)$ and the base peak at $\mathrm{m} / z 50$.
Synthesis of 2R, 3S, 4R, 5S-2-(4,6-diaryl-3-carbonitrile)-2thioxo-1(2H)-pyridin-yl)-5'-hydroxy-tetrahydro-2H-pyran3,4-di-yl) diacetate $(17 \mathrm{a}, \mathrm{b})$

A suspension of the thiocyanopyridine derivatives $7 \mathrm{a}$ and/or $7 \mathrm{~b}$ $(0.01 \mathrm{~mol})$ in $6 \mathrm{ml}$ of aqueous $\mathrm{KOH}$ solution (prepared from dissolving $(0.01 \mathrm{~mol})$ solid $\mathrm{KOH}$ in $6 \mathrm{ml}$ of distilled water) was well stirred (magnetic stirrer) at room temperature for $3 \mathrm{hrs}$, then a solution of 12 $(0.01 \mathrm{~mol})$ dissolved in $30 \mathrm{ml}$ of dry acetone was added drop-wise while stirring. Stirring was continued for further $12 \mathrm{~h}$. After evaporation of the excess solvent (reduced pressure), the residue left was washed with dilute alcohol (several times) and the precipitate formed was recrystallized from ethanol as $17 \mathrm{a}, \mathrm{b}$.

$17 \mathrm{a}$ as red crystals, in yield $70 \%$, m.p $146^{\circ} \mathrm{C}$. [Requires: C, 59.10; H, 4.39; N, 4.92; Cl, 6.24; S,5.62 ; Found C, 59.32; H, 4.5; N,5.10; Cl, 6.34; S, 5.78\%]; IR cm-13436.5, 2220.4, 1600.6, 1248.6 and 526.4 for $\mathrm{OH}, \mathrm{C} \equiv \mathrm{N}, \mathrm{C}=\mathrm{N}, \mathrm{C}=\mathrm{S}$ and $\mathrm{C}-\mathrm{Cl}$.

$17 \mathrm{~b}$ as black crystals, in $60 \%$ yield, m.p. $184^{\circ} \mathrm{C}$. Requires: C, 56.76 ; H, 3.97; N, 5.29; Cl, 6.72; S, 6.05; Found: C, 56.87; H, 4.01; N, 5.43; Cl, 6.9; S, 6.32; IR $\left(\mathrm{cm}^{-1}\right): 3300,2228,1597,1232$ and $525(\mathrm{C}-\mathrm{Cl})$.

Synthesis of 2S,3S,4R,5S-2-(6-(4-chlorophenyl)-4-(2bromophenyl)-2,3,4,5-tetrahydro-pyrimidin-1-yl)mercapto5-hydroxy tetrahydro-2H-pyran-3,4-diyl diacetate (18a) and 2S,3S,4R,5S-2-(6-(phenyl)-4-(2-bromophenyl)-2,3,4,5-tetrahydro-pyrimidin-1-yl)-mercapto-5-hydroxy tetrahydro- $2 \mathrm{H}$ pyran-3,4-diyl diacetate (18b)

A suspension of the pyrimidin-2-thione derivatives (10a) and/ or $(10 \mathrm{c})(0.01 \mathrm{~mol})$ in $6 \mathrm{ml}$ of aqueous $\mathrm{KOH}$ solution (prepared from dissolving $(0.01 \mathrm{~mol})$ solid $\mathrm{KOH}$ in $6 \mathrm{ml}$ of distilled water) was well stirred (magnetic stirrer) at room temperature for $3 \mathrm{~h}$, then a solution of $12(0.01 \mathrm{~mol})$ dissolved in $30 \mathrm{ml}$ of dry acetone was added dropwise while stirring. Stirring was continued for further $12 \mathrm{~h}$. After evaporation of the excess solvent (reduced pressure), the residue left was washed with dilute alcohol (several times) and the precipitate formed was recrystallized from ethanol to give (18a,b).

$18 \mathrm{a}$ as grey crystals, in $70 \%$ yield, m.p. $188^{\circ} \mathrm{C}$.

Requires: C, 50.46; H, 3.86; N, 4.71; S; 5.38; Cl, 6.24; Br, 13.4; Found: C, 50.52; H, 3.98; N, 4.81; S, 5.45; Cl, 5.45; Br, 13.5; IR (cm $\left.{ }^{1}\right) 3398,2652,1671,1563,625$ and $518(\mathrm{C}-\mathrm{Br}) .{ }^{1} \mathrm{H}-\mathrm{NMR}$ spectrum $\left(\right.$ DMSO-d $\left._{6}\right): \delta 1.19,2.49$ (s, 6H, 2x $\left.\mathrm{COCH}_{3}\right), \delta 3.32\left(\mathrm{~d}, 2 \mathrm{H}, \mathrm{CH}_{2}\right), 4.29$ (t, 1H, CH), 5.37, 5.38(d, 1H, CH), 5.40, $5.41(\mathrm{~d}, 1 \mathrm{H}, \mathrm{CH}), 7.23-7.64$ (m, 9H, Ar-H), 9.05 (s, 1H, SH), 9.99 (s, 1H, OH).

$18 \mathrm{~b}$ as white crystals, in $75 \%$ yield, m.p. $154^{\circ} \mathrm{C}$. Requires: C, 53.57 ; H, 4.28; N, 5.00; S, 5.71; Br, 14.3; Found: C, 53.87; H, 4.31; N, 5.01; S, 5.82; Br, 14.4; IR $\left(\mathrm{cm}^{-1}\right): 3394,2644,1657,1569,549$ (C-Br). ${ }^{1} \mathrm{H}-\mathrm{NMR}$ $\left(\right.$ DMSO-d $\left._{6}\right): \delta 1.01,2.49\left(\mathrm{~s}, 6 \mathrm{H}, 2 \mathrm{x} \mathrm{COCH}_{3}\right) \neg, 3.43\left(\mathrm{~d}, 2 \mathrm{H}, \mathrm{CH}_{2}\right), \delta 4.29$ (d, $\left.2 \mathrm{H}, \mathrm{CH}_{2}\right), 5.39(\mathrm{t}, 1 \mathrm{H}, \mathrm{CH}), 7.06-7.96(\mathrm{~m}, 8 \mathrm{H}, \mathrm{Ar}-\mathrm{H}), 9.09(\mathrm{~s}, 1 \mathrm{H}$, $\mathrm{SH}), 10.10$ (s, $1 \mathrm{H}, \mathrm{OH})$. MS ( $\mathrm{m} / \mathrm{z}, \%): 424 \mathrm{M}^{+2}(0.02 \%)$.

\section{Synthesis of nucleoside derivatives (19a-c)}

A suspension of pyrimidin-2-thione derivatives (10b,d,e) $(0.01$ $\mathrm{mol}$ ) in $6 \mathrm{ml}$ of aqueous $\mathrm{KOH}$ solution (prepared from dissolving $(0.01$ mol) solid $\mathrm{KOH}$ in $6 \mathrm{ml}$ of distilled water) was well stirred (magnetic stirrer) at room temperature for $3 \mathrm{~h}$, then a solution of $12(0.01 \mathrm{~mol})$ dissolved in $30 \mathrm{ml}$ of dry acetone was added drop-wise while stirring. Stirring was continued for further $12 \mathrm{~h}$. After evaporation of the excess solvent (reduced pressure), the residue left was washed with dilute 
alcohol (several times) and the precipitate formed was recrystallized from ethanol to give $(19 a-c)$.

$19 \mathrm{a}$, as Grey crystals, in $70 \%$ yield, m.p. $120^{\circ} \mathrm{C}$. Requires: C, 54.64; H, 4.01; N, 5.10; S, 5.82; Cl; 12.9; Found: C, 50.72; H, 4.21; N, $5.21 ; \mathrm{S}, 5.95 ; \mathrm{Br}, 13.1 ; \mathrm{IR}\left(\mathrm{cm}^{-1}\right): 3294,1674,1552,1256,728(\mathrm{C}-\mathrm{Cl})$. ${ }^{1} \mathrm{H}-\mathrm{NMR}$ (DMSO-d6): $\delta$ 2.49, $2.50\left(\mathrm{~d}, 2 \mathrm{H}, \mathrm{CH}_{2}\right), 3.33,3.44,3.59$ (t, $1 \mathrm{H}-\mathrm{CH}$ ), 3.71, 4.33 (d, 1H, CH1'-CH2'), 5.380, 5.385 (d, 1H, CH2'), 5.39, $5.40\left(\mathrm{~d}, 1 \mathrm{H}, \mathrm{CH} 3{ }^{\prime}\right), 5.44,5.45,5.46(\mathrm{t}, 1 \mathrm{H}, \mathrm{CH} 4), 5.47,6.65(\mathrm{~d}$, $2 \mathrm{H}, \mathrm{CH} 25$ '), 6.82-7.73 (m, 8H, Ar-H), and at 10.06 (s, 1H, OH). MS $(\mathrm{m} / \mathrm{z}, \%): 478(0.55 \%)$.

$19 \mathrm{~b}$ as orange crystals, in $75 \%$ yield, m.p. $190^{\circ} \mathrm{C}$. IR $\left(\mathrm{cm}^{-1}\right): 3401$, 1670, 1595, 1240, 752 (C-Cl). ${ }^{1} \mathrm{H}-\mathrm{NMR}$ (DMSO-d6): $\delta 2.49,2.50(\mathrm{~d}$, $\left.2 \mathrm{H}, \mathrm{CH}_{2}\right), 3.43$ (t, 1H, CH), 6.76, 6.77 (d, 1H, CH25'), 6.99-7.61 (m, $7 \mathrm{H}, \mathrm{Ar}-\mathrm{H}), 8.18(\mathrm{~s}, 1 \mathrm{H}, \mathrm{OH})$. MS ( $/ \mathrm{z}, \%): 480 \mathrm{M}^{+1}(0.22 \%)$.

$19 \mathrm{c}$ as black crystals, $60 \%$ yield, m.p. $224^{\circ} \mathrm{C}$. Requires: C, 54.71 ; H, 4.16; N, 5.55; S, 6.34; Cl, 7.03; Found C, 54.89; H, 4.32; N, 5.76; $\mathrm{S}, 6.56 ; \mathrm{Cl}, 7.12$; IR $\left(\mathrm{cm}^{-1}\right): 3343-3225,1740,1602,1243 .{ }^{1} \mathrm{H}-\mathrm{NMR}$ $\left(\mathrm{DMSO}_{\mathrm{d}}\right.$ ): $\delta 3.55\left(\mathrm{~s}, 3 \mathrm{H}, \mathrm{OCH}_{3}\right), 5.93(\mathrm{~s}, 1 \mathrm{H}, \mathrm{NHCO}), 7.01-7.90(\mathrm{~m}$, $13 \mathrm{H}, \mathrm{Ar}-\mathrm{H}), 10.1$ (s, $1 \mathrm{H}, \mathrm{OH})$. MS ( $\mathrm{m} / \mathrm{z}, \%): 300 \mathrm{M}^{+2}(0.59 \%)$.

Synthesis of (2R,3S,4R,5S)-2(4(-2-chlorophenyl)-6phenyl-4'-1,3-oxazine-2-ylamino)-5'-hydroxytetrahydro -2H-pyran-3',4'-diyl diacetate (20a) and (2R,3S,4R,5S)-2(6(4-benzamidophenyl)-4-(4-methoxyphenyl)-4H-1,3-oxazin2-ylamino) - 5 '-hyd roxytetrahydro- $2 \mathrm{H}$-pyran-3', $4^{\prime}$-diyl diacetate (20b)

A suspension of the Oxazine derivatives 11a and/or $11 \mathrm{~b}(0.01 \mathrm{~mol})$ in $6 \mathrm{ml}$ of aqueous $\mathrm{KOH}$ solution (prepared from dissolving $(0.01 \mathrm{~mol})$ solid $\mathrm{KOH}$ in $6 \mathrm{ml}$ of distilled water) was well stirred (magnetic stirrer) at room temperature for $3 \mathrm{~h}$, then a solution of $12(0.01 \mathrm{~mol})$ dissolved in $30 \mathrm{ml}$ of dry acetone was added drop-wise while stirring. Stirring was continued for further $12 \mathrm{~h}$. After evaporation of the excess solvent (reduced pressure), the residue left was washed with dilute alcohol (several times) and the precipitate formed was recrystallized from ethanol to give 20a,b.

$20 \mathrm{a}$ as pale yellow crystals, $60 \%$ yield, m.p. $158-160^{\circ} \mathrm{C}$. Requires: C, 64.39; H, 5.36; N, 6.82; Found: C, 64.94; H, 5.40; N, 6.8. IR $\left(\mathrm{cm}^{-1}\right)$ : 3482, 3302, 1654, 1666, 1591. ${ }^{1} \mathrm{H}-\mathrm{NMR}\left(\right.$ DMSO-d $\left._{6}\right): \delta 2.49,2.495(\mathrm{~s}$, $\left.6 \mathrm{H}, 2 \mathrm{xCOCH}_{3}\right), 3.91\left(\mathrm{~s}, 2 \mathrm{H}, \mathrm{CH}_{2}\right), 4.0(\mathrm{~d}, 2 \mathrm{H}, \mathrm{CH}-\mathrm{CH}), 4.06(\mathrm{~s}, 1 \mathrm{H}$, $\mathrm{NH}), 7.42$ - 7.82 (m, 9H, Ar-H), 8.05 (s, 1H, OH).

$20 \mathrm{~b}$ as yellow crystals, $60 \%$ yield, m.p. $110-112^{\circ} \mathrm{C}$. Requires: C, 59.94; H, 4.99; N, 5.59; Cl, 7.09; Found: C, 60.1; H, 5.0; N, 5.6; Cl, 7.1. IR $\left(\mathrm{cm}^{-1}\right): 3482,3302,1654,1666,1591,1593 .{ }^{1} \mathrm{H}-\mathrm{NMR}$ (DMSO-d $\left.{ }_{6}\right): \delta$ $6.9 \mathrm{~d}, 2 \mathrm{H}-\mathrm{CH}-\mathrm{CH}) 2.1-2.6\left(\mathrm{~s}, 6 \mathrm{H}, 2 \mathrm{xCOCH}_{3}\right), 10.2(\mathrm{~s}, 1 \mathrm{H}, \mathrm{NH}), 10.5$ (s, $1 \mathrm{H}, \mathrm{OH}), 3.8\left(\mathrm{~s}, 3 \mathrm{H}, \mathrm{OCH}_{3}\right)$, and $7.02-8.13\left(\mathrm{~m},{ }^{13} \mathrm{H}-\mathrm{Ar}\right) .{ }^{13} \mathrm{C}-\mathrm{NMR}$ $\left(\right.$ DMSO-d $\left._{6}\right): \delta 24.1,26.4,38.6,55.3$.

\section{Results and Discussion}

1,3-diaryl-1-propen-3-ones, 1a-h, which were synthesized according to the literature [34], were used as starting material for the synthesis of a large range of heterocyclic compounds (compound series 2-6) as depicted in Scheme 1.

Thus, condensation of $1 \mathrm{~h}$ with excess of hydrazine hydrate in dry ethanol led to the formation of the corresponding $\mathrm{N}$-[4-(5-(4'methoxyphenyl)-4,5-dihydro-1H-pyrazol-3-yl]phenyl)benzamide 2 [35-37]. The infrared spectrum of 2 showed absorption bands at 3340, 1650,1600 due to $\mathrm{v}_{\mathrm{NH}}, \mathrm{v}_{\mathrm{C}=\mathrm{O}}$ (amide) and $\mathrm{v}_{\mathrm{C}=\mathrm{N}}$, respectively. Compound 1f reacted with ethyl acetoacetate $(1: 1)$ under the same conditions to afford ethyl 6-(2-chlorophenyl)-2-oxo-4-phenylcyclohex-3-ene carboxylate 3 [38-40] which reacted with hydrazine hydrate affording 4 [41]. The IR spectrum of 3 showed absorption bands at 1698, 1660 $\mathrm{cm}^{-1}$ due to two $\mathrm{C}=\mathrm{O}$ groups, while its $\mathrm{MS}$ showed a molecular ion peak at $\mathrm{m} / \mathrm{z}$ 355. The IR spectrum of 4 showed absorption bands at 3392 and 3216 for $(\mathrm{NH} / \mathrm{OH}), 1670(\mathrm{CONH})$ and $1604(\mathrm{C}=\mathrm{N})$. The mass spectrum of 4 revealed a molecular ion peak at $\mathrm{m} / \mathrm{z} 322$.

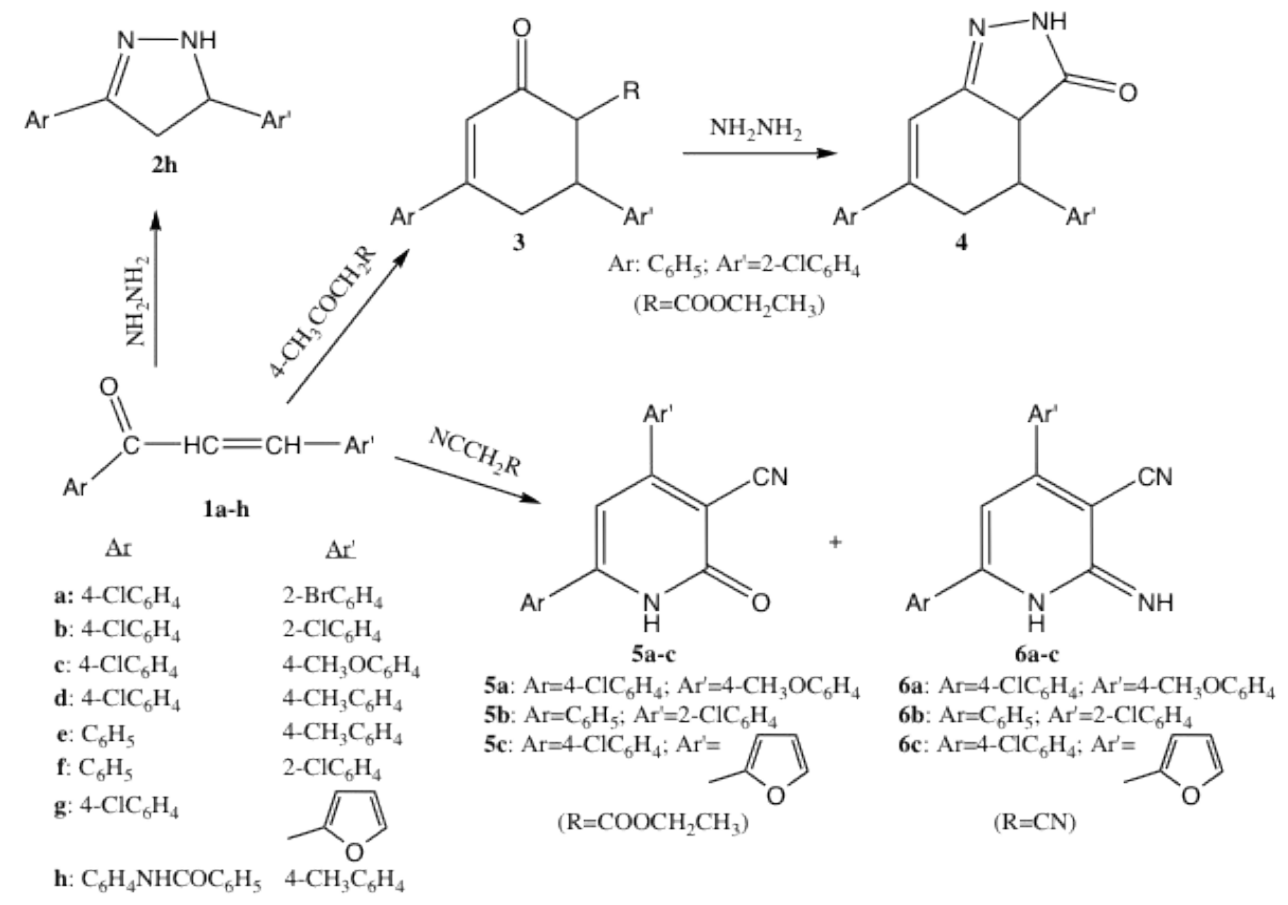

Scheme 1: Heterocycle synthesis from 1,3-diaryl-1-propen-3-ones. 
Reaction of $1 \mathrm{c}, \mathrm{f}, \mathrm{g}$ with active methylene compounds namely, ethyl cyanoacetate and /or malononitrile [42] in the presence of ammonium acetate afforded the corresponding 4,6-diaryl-2-oxo-1,2-dihydropyridine-3-carbonitrile 5a-c and 2-imino-4,6-diaryl-1,2-dihydro-3cabonitrile 6a-c, respectively (Scheme 1). The infrared spectra of 5a-c showed absorption bands (in $\mathrm{cm}^{-1}$ ) at 3460-3230 (NH/OH), 2230-2210 $(\mathrm{C} \equiv \mathrm{N})$ and 1654-1662 due to the amide $\mathrm{C}=\mathrm{O}$, while the infrared spectra of 6a-c showed N-H absorption bands at 3366 and $3114 \mathrm{~cm}^{-1}, \mathrm{C} \equiv \mathrm{N}$ bands at 2220 and $2212 \mathrm{~cm}^{-1}$ and were devoid of $v_{\mathrm{C}=0}$. The ${ }^{1} \mathrm{H}-\mathrm{NMR}$ spectrum of $5 \mathrm{a}$ (DMSO-d $\mathrm{d}_{6}$ ) showed signals at $\delta 3.83 \mathrm{ppm}$ due to three $\mathrm{OCH}_{3}$ protons, $8.28 \mathrm{ppm}$ due to one $\mathrm{NH}$ proton and an aromatic multiplet at $\delta 7.12-8.00 \mathrm{ppm}$. Its MS spectrum showed a molecular ion peak at $m / z 336.3$.

Scheme 2 depicts the reactions undertaken with cyanopyridone derivatives $5 \mathrm{a}$,c. The reaction of $5 \mathrm{a}, \mathrm{c}$ with phosphorus pentasulphide in a non-polar solvent, (e.g., xylene under reflux) afforded the corresponding 4,6-diaryl-2-thioxo-1,2-dihydropyridin-3-carbonitrile derivatives 7a-b. The IR spectra showed absorption bands at 3354, $3437,1218,1212 \mathrm{~cm}^{-1}$ for $\mathrm{NH}$ and $\mathrm{C}=\mathrm{S}$, respectively. The mass spectrum of 7a revealed a molecular ion peak at $\mathrm{m} / \mathrm{z} 352.5$. The reaction of compound $5 \mathrm{a}$ with $40 \% \mathrm{H}_{2} \mathrm{SO}_{4}-\mathrm{AcOH}$ afforded the corresponding 4,6-diaryl-2-oxo-1,2-dihydropyridine-3-carboxamide derivative 8a. Its IR spectrum revealed absorption bands at 1648 due to the presence of $\mathrm{C}=\mathrm{O}, \mathrm{NH} / \mathrm{OH}$ at $3410,3464 \mathrm{~cm}^{-1}$ and were devoid of absorptions arising from the presence of $\mathrm{C} \equiv \mathrm{N}$. In a similar manner, hydrolysis of $5 \mathrm{a}$ in ethanolic $\mathrm{NaOH}(25 \%)$ accompanied by oxidation with $\mathrm{H}_{2} \mathrm{O}_{2}$ afforded the corresponding 4,6-diaryl-2-oxo-1,2-dihydropyridin-3carboxylic acid 9a. Its IR spectrum revealed the presence of broad $\mathrm{OH}$ and $\mathrm{NH}$ absorption bands at 3433 and $3200 \mathrm{~cm}^{-1}, 1686 \mathrm{du}$, a strong $\mathrm{C}=\mathrm{O}$ stretch and was devoid of any absorption for $\mathrm{CN}$.

The reactions of 1,3-diaryl-2-propen-1-ones 1a,b,e,g and $1 \mathrm{~h}$ with thiourea in boiling absolute ethanol containing sodium ethoxide afforded the corresponding 4,6-diaryl pyrmidine-2-thione derivatives $10 \mathrm{a}-\mathrm{e}$ in reasonable yields, while its reaction with urea under acid catalyzed conditions afforded the corresponding 2-amino-4,6-diaryl1,3-oxazine derivatives 11a-c respectively (Scheme 3 ).

The infrared spectra of 10a-e displayed absorption bands at 3408$3140 \mathrm{~cm}^{-1}, 1112$ and $1012 \mathrm{~cm}^{-1}$, due to $\mathrm{NH}$, and $\mathrm{C}=\mathrm{S}$, respectively. The ${ }^{1} \mathrm{H}-\mathrm{NMR}$ spectrum of $10 \mathrm{~b}$ showed signals at $\delta 2.09$ and $2.46 \mathrm{ppm}$ due to two $\mathrm{CH}_{2}$ protons, $\delta 7.82-8.12 \mathrm{ppm}$ due to an aromatic multiplet and one $\mathrm{D}_{2} \mathrm{O}$ exchangeable signal at $\delta 10.27 \mathrm{ppm}$ due to an $\mathrm{NH}$ proton. The structure of $11 \mathrm{a}-\mathrm{c}$ was confirmed by infrared spectrum, which revealed the presence of $\mathrm{N}-\mathrm{H}$ stretches at $3348-3200 \mathrm{~cm}^{-1}$. The ${ }^{1} \mathrm{H}-\mathrm{NMR}$ spectrum of $11 \mathrm{~b}$ showed signals at $\delta 2.1 \mathrm{ppm}$ due to two $\mathrm{NH}_{2}$ protons, $\delta 3.81$ and $3.82 \mathrm{ppm}$ due to a CHa proton, $\delta 6.9,7.02$ for a $\mathrm{CHb}$ proton

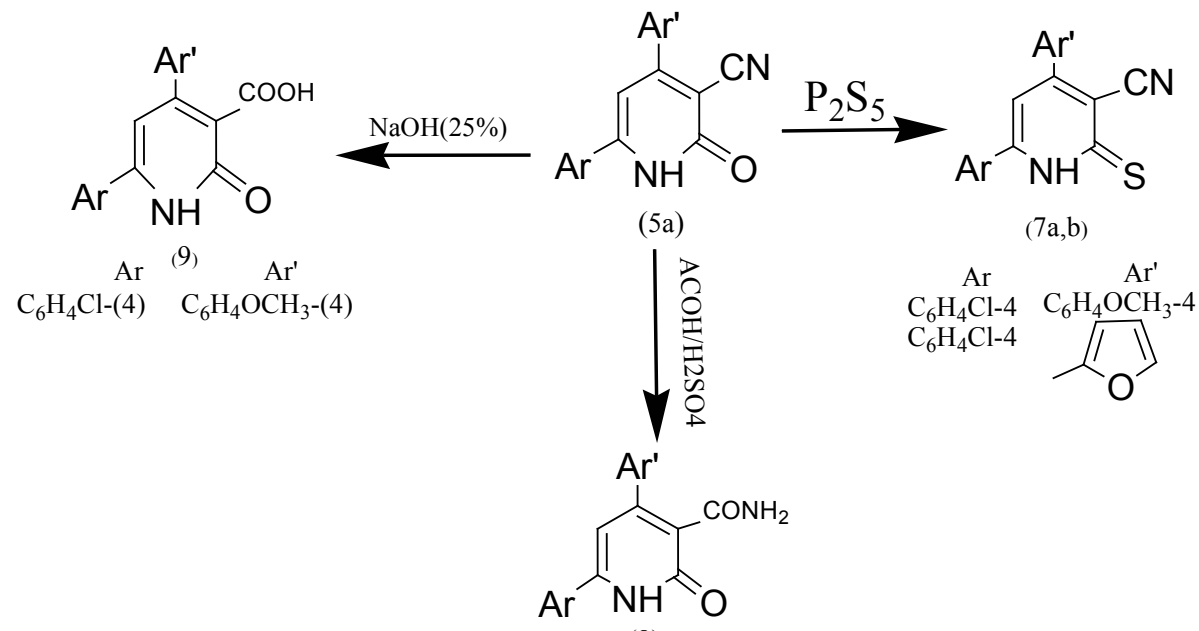

(8)

$$
\begin{array}{rc}
\mathrm{Ar} & \mathrm{Ar}^{\prime} \\
\mathrm{C}_{6} \mathrm{H}_{4} \mathrm{Cl}(4) & \mathrm{C}_{6} \mathrm{H}_{4} \mathrm{OCH}_{3}-(4)
\end{array}
$$

Scheme 2: Functionalizations of 5a,c.

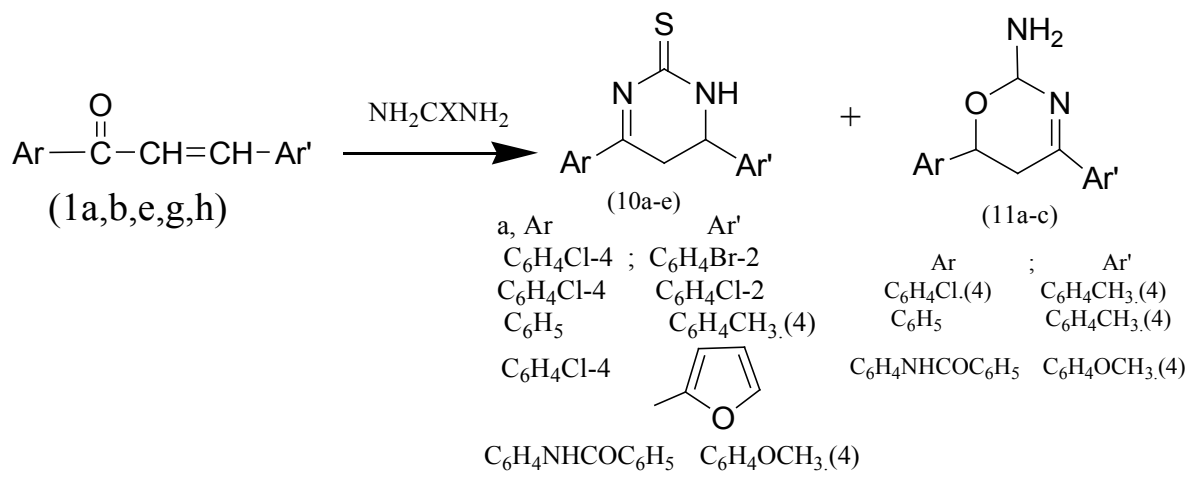

Scheme 3: Heterocyclization reactions with $\mathbf{1 a}, \mathbf{b}, \mathbf{e}, \mathbf{g}, \mathbf{h}$ 
and a multiplet for the aromatic protons at $\delta 7.5-8.1 \mathrm{ppm}$. The ${ }^{13} \mathrm{C}-\mathrm{NMR}$ spectrum showed signals at $\delta 37.2\left(\mathrm{C}_{1}\right), 161.1\left(\mathrm{C}_{2}\right), 97.07\left(\mathrm{C}_{3}\right), 168.8$ $\left(\mathrm{C}_{4}\right), 130.5\left(\mathrm{C}_{5}\right), 127.7\left(\mathrm{C}_{6}\right), 139.3\left(\mathrm{C}_{7}\right), 143.4\left(\mathrm{C}_{8}\right), 134.5\left(\mathrm{C}_{9}\right), 127.3$ $\left(\mathrm{C}_{10}\right), 143.1\left(\mathrm{C}_{1}{ }^{\prime}\right), 129.6\left(\mathrm{C}_{3}{ }^{\prime}\right), 131.8\left(\mathrm{C}_{6}{ }^{\prime}\right), 128.3\left(\mathrm{C}_{5}{ }^{\prime}\right), 127.7\left(\mathrm{C}_{2}{ }^{\prime}\right)$, $119.4\left(\mathrm{C}_{4}{ }^{\prime}\right)$ and its mass spectrum showed a molecular ion peak $\mathrm{m} / \mathrm{z}$ at 284.8 .

Interaction of $\alpha$-D-xylopyranosyl bromide 12 with the desired heterocycles in aqueous potassium hydroxide afforded the corresponding heterocycles incorporating tetrahydro-2H-pyran-3,4diyldiacetates (13-20). See Scheme 4.

Reaction of compound 2 with 2,3,4,6-tetra- $O$-acetyl- $\alpha$-Dglucopyranosyl bromide 12 gave the corresponding 13. Its infrared spectrum revealed the presence of absorption bands at 1663, 1600, and $3346 \mathrm{~cm}^{-1}$ due to $\mathrm{CONH}$ and $\mathrm{NH} / \mathrm{OH}$ respectively. The ${ }^{1} \mathrm{H}-\mathrm{NMR}$ $\left(\mathrm{DMSO}_{6} \mathrm{~d}_{6}\right.$ ) of 13 showed a doublet for anomeric protons at $\delta 6.9,7.0$ ppm due to diaxial orientations of $\mathrm{H}-1^{\prime}$ and $\mathrm{H}-2$ ' protons, indicating their presence in the $\beta$-configuration and the other protons of the xylopyranosyl resonating in the region 3.3-3.7 ppm, while the protons of the two acetyl moieties showed as two singlets at $\delta 2.41$ and 2.43 $\mathrm{ppm}$. The presence of the two $\mathrm{OH}$ protons was indicated by two singlets at $\delta 10.04$ and $10.52 \mathrm{ppm}$. The mass spectrum of 13 showed a molecular ion peak at $\mathrm{m} / \mathrm{z} 575$ indicating the partial hydrolysis of one acetyl and the metonym groups in the molecule to the corresponding $\mathrm{OH}$ group.

Similarly $\alpha$-D-xylopyranosyl bromide 12 was reacted with the indazolone 4 under the same conditions to give the corresponding (2R,3S,4R,5S)-5-hydroxy-2-[3-oxo-(4-phenyl-5-(2-chlorophenyl)3,3a,4,5-tetrahydro-2H-indazol-2-yl)tetrahydro-2H-pyran-3,4-diyl diacetate 14. Its IR spectrum revealed the presence of absorption bands at $3443 \mathrm{~cm}^{-1}(\mathrm{OH}), 1742 \mathrm{~cm}^{-1}(\mathrm{C}=\mathrm{O})$ and an absorption band at 1376 $\mathrm{cm}^{-1}$ due to an out of plane $\mathrm{CH}_{3}$. On the other hand, 2, 3, 4, 6-tetra$O$-acetyl- $\alpha$-D-glucopyranosyl bromide 12 reacted with $5 \mathrm{c}$ and $6 \mathrm{c}$ in acetone and aqueous potassium hydroxide to afford the corresponding nucleosides derivatives 15 and 16, respectively. The IR spectra of 15 and 16 showed absorption bands at 3315-3314 $\mathrm{cm}^{-1}$ (br) and 1655-1648 $\mathrm{cm}^{-1}$ due to $\mathrm{OH} / \mathrm{NH}$ and $\mathrm{C}=\mathrm{O}$ groups, respectively. Spectral results showed that the electron withdrawing character of 4-chlorophenyl and the furan ring at positions 4 and 6 in the pyridine ring of the nucleosides 15 and 16 were helpful in the partial hydrolysis of the cyan group at position 3 of the pyridine moiety as evidenced by the fact that no cyano stretching absorption band was observed in the IR. The ${ }^{1} \mathrm{H}-\mathrm{NMR}$ spectrum of 15 (DMSO- $\mathrm{d}_{6}$ ) showed signals at $\delta 4.41 \mathrm{ppm}$ due to $\mathrm{NH}$ protons, an aromatic multiplet at $\delta 6.68-7.90 \mathrm{ppm}$, two doublets at $\delta$ 8.05 and $8.07 \mathrm{ppm}$ due to $\mathrm{OH}$ protons, triplets at $\delta 3.3,3.41,3.44 \mathrm{ppm}$ due to $\mathrm{CH}_{2}$ protons and a singlet at $8.07 \mathrm{ppm}$ due to $\mathrm{NH}_{2}$ protons. Its mass spectrum showed a molecular ion peak at $\mathrm{m} / \mathrm{z}$ 497.45. The ${ }^{1} \mathrm{H}-\mathrm{NMR}$ spectrum of 16 (DMSO-d $\mathrm{d}_{6}$ ) showed signals at $\delta 1.97$ and 2.49 ppm as two singlets arising from the two $\mathrm{COCH}_{3}$ groups at $\mathrm{C}_{2}^{\prime}, \mathrm{C}_{3}^{\prime}$, a singlet signal at $\delta 6.55 \mathrm{ppm}$ due to proton in the pyridine moiety, two doublets at $\delta 2.44$ and $3.44 \mathrm{ppm}$ due to two anomeric protons at $\mathrm{C}_{2}$ and $\mathrm{C}_{3}^{\prime}$, a multiplet at $\delta 6.82-7.94 \mathrm{ppm}$ for the aromatic protons and two signals, one at $\delta 8.12 \mathrm{ppm}$ for the $\mathrm{NH}_{2}$ and at $9.75 \mathrm{ppm}$ due to the $\mathrm{OH}$ proton at $\mathrm{C}_{4}$. Its mass spectrum showed the molecular ion peak at $m / z 511.5$.

The reaction of 2,3,4-tri-O-acetyl- $\alpha$-D-xylopyranosyl bromide 12 with 4,6-diaryl-3-cyano-2-thioxo-1-(2H)-pyridines $7 \mathrm{a}$ and $\mathrm{b}$ afforded the corresponding $2 \mathrm{R}, 3 \mathrm{~S}, 4 \mathrm{R}, 5 \mathrm{~S}-2$-(4,6-diaryl-3-carbonitrile)-2-thioxo1(2H)-pyridin-yl)-5'-hydroxy-tetrahydro-2H-pyran-3,4-diyl)diacetates $17 \mathrm{a}$ and $\mathrm{b}$, respectively. This is supported by the presence of $\mathrm{C} \equiv \mathrm{N}$ stretching absorptions at 2220 and $2228 \mathrm{~cm}^{-1}$ and 1248 and $1232 \mathrm{~cm}^{-1}$ for the $\mathrm{C}=\mathrm{S}$ moiety. The mass spectrum of 17 a showed molecular ion peak at $m / z$ 351.5. The electron releasing effect of $\mathrm{OCH}_{3}$ at position-4 of the aromatic moiety was balanced by the electron withdrawing effect of the chlorophenyl, thereby stabilizing the cyano group at position 3 towards alkaline hydrolysis. The electronic character of

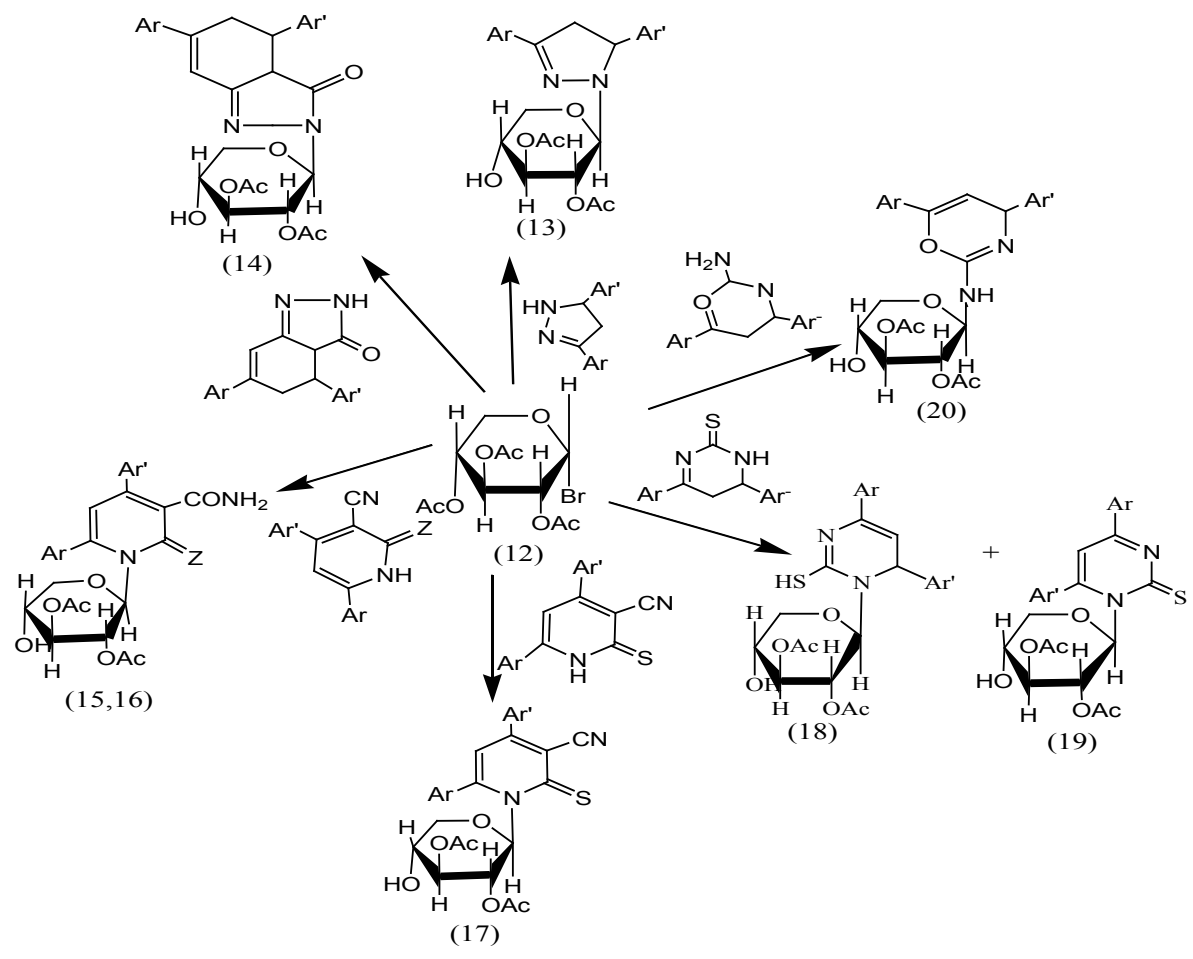

Scheme 4: Reaction of Compound 12 with Heterocycles. 
the sulphur moiety at carbon 2 may also have helped stabilize the $-\mathrm{C} \equiv \mathrm{N}$ group towards the effect of the alkali on the compound $17 \mathrm{~b}$. Interaction of 2,3,4-tri-O-acetyl- $\alpha$-D-xylopyranosyl bromide 12 with pyrimidine thione derivatives $10 \mathrm{a}$ and $10 \mathrm{c}$ in aqueous $\mathrm{KOH} /$ acetone afforded the corresponding 2S,3S,4R,5S-2-(6-(phenyl)-4-(2-bromo phenyl)-2,3,4,5-tetrahydro-pyrimidin-1-yl)-mercapto-5-hydroxy tetra hydro-2H-pyran-3,4-diyl)diacetate (18a) and 2S,3S,4R,5S-2-(6-(4chloro phenyl)-4-(2-bromo phenyl)-2,3,4,5-tetrahydro-pyrimidin-1yl)mercapto-5-hydroxytetrahydro-2H-pyran-3,4-diyl)diacetate (18b), respectively. The IR spectra of $18 \mathrm{a}$ and $18 \mathrm{~b}$ revealed weak absorption bands arising from SH stretching at 2652 and $2644 \mathrm{~cm}^{-1}$ and were devoid of $\mathrm{C}=\mathrm{S}$ absorptions. The ${ }^{1} \mathrm{H}-\mathrm{NMR}$ spectrum of $18 \mathrm{a}\left(\mathrm{DMSO}_{6}\right)$ showed signals at $\delta 1.19 \mathrm{ppm}, 2.49 \mathrm{ppm}\left(\mathrm{COCH}_{3}\right.$ protons $), \delta 3.32 \mathrm{ppm}$ due to $\mathrm{CH}_{2}$ protons, $\delta 4.29 \mathrm{ppm}$ (CH proton), a multiplet at $\delta$ 7.23-7.64 ppm, $\delta 9.05$ (SH proton) and at $\delta 9.99 \mathrm{ppm}$ due to $\mathrm{OH}$ proton. The mass spectrum of $18 \mathrm{~b}$ showed a molecular ion peak at $\mathrm{m} / \mathrm{z} 424$.

Furthermore, 2,3,4-tri-O-acetyl- $\alpha$-D-xylopyranosyl bromide 12 reacted with other pyrimidine thione derivatives $10 \mathrm{~b}, \mathrm{~d}$ and $\mathrm{e}$ in aqueous $\mathrm{KOH} /$ acetone to afford the corresponding nucleosides $19 \mathrm{a}-$ c. The infrared spectra of 19a-c revealed the presence of absorption bands at $3401,3343,3294,1740,1674,1670,1256-1240 \mathrm{~cm}^{-1}$ for $\mathrm{OH} / \mathrm{NH}, \mathrm{C}=\mathrm{O}$ and $\mathrm{C}=\mathrm{S}$ functionalities. The ${ }^{1} \mathrm{H}-\mathrm{NMR}$ spectrum of $19 \mathrm{a}$ (DMSO- $\mathrm{d}_{6}$ ) showed signals at $\delta 2.49$ and $2.50 \mathrm{ppm}$ due to $\mathrm{CH}_{2}$ protons, $\delta 5.39$ and $5.40 \mathrm{ppm}$ due to three $\mathrm{CH}_{3}$ protons, and at $\delta 10.06 \mathrm{ppm}$ due to $\mathrm{OH}$ protons, while its MS showed a molecular ion peak at $\mathrm{m} / \mathrm{z} 300$. The ${ }^{1} \mathrm{H}-\mathrm{NMR}$ spectrum of 20c (DMSO-d $\mathrm{d}_{6}$ ) showed signals at $\delta 3.55$ ppm due to three $\mathrm{OCH}_{3}$ protons and $\delta 5.93 \mathrm{ppm}$ due to NHCO proton. Interaction of 2-amino-4,6-diaryl-1,3-oxazine derivatives $11 \mathrm{~b}$ and $11 \mathrm{c}$ with 2,3,4-tri-O-acetyl- $\alpha$, D-xylo pyranosyl bromide 12 afforded the corresponding nucleosides $20 \mathrm{a}$ and $20 \mathrm{~b}$, respectively. The infrared spectra of $20 \mathrm{a}$ and $20 \mathrm{~b}$ revealed absorption bands at $3482,3302,1654$, $1666 \mathrm{~cm}^{-1}$, due to $\mathrm{OH} / \mathrm{NH}$ and $\mathrm{C}=\mathrm{O}$ groups. The ${ }^{1} \mathrm{H}-\mathrm{NMR}\left(\mathrm{DMSO}-\mathrm{d}_{6}\right)$ of 20a showed singlet signals at $\delta 2.49$ and $2.495 \mathrm{ppm}$ due to two acetyl groups, a singlet at $\delta 3.91 \mathrm{ppm}$ due to pyran $\mathrm{CH}_{2}$ units, a doublet at $\delta$ $4.0 \mathrm{ppm}$ (oxazine ring $\mathrm{CH}-\mathrm{CH}$ ), a singlet at $\delta 4.06 \mathrm{ppm}$ due to $\mathrm{NH}$ proton, a multiplet due to the aromatic protons at $\delta 7.42-7.82 \mathrm{ppm}$ and a singlet at $\delta 8.05 \mathrm{ppm}$ due to $\mathrm{OH}$ protons. Its mass spectrum showed a molecular ion at $m / z$ 484.5. The ${ }^{1} \mathrm{H}-\mathrm{NMR}$ (DMSO-d ${ }_{6}$ ) of $20 \mathrm{~b}$ showed a doublet at $\delta 6.9 \mathrm{ppm}$ due to anomeric protons of $\mathrm{C}-1^{\prime}, \mathrm{C}-2^{\prime}$ indicating the presence of a $\beta$ configuration and the other protons of the xylopyranozyl at $\delta 2.4-2.5 \mathrm{ppm}$. The acetyl protons showed two singlets at $\delta 2.1 \mathrm{ppm}$ and $2.6 \mathrm{ppm}$, the $\mathrm{NH}$ proton showed a singlet at $\delta$ $10.2 \mathrm{ppm}$. The $\mathrm{OH}$ proton of $\mathrm{C}_{4}$, resonated at $\delta 10.5 \mathrm{ppm}$, three protons of the methoxy group showed a singlet at $\delta 3.8 \mathrm{ppm}$, while the aromatic protons gave a multiplet at $\delta 7.02-8.13 \mathrm{ppm}$. Its ${ }^{13} \mathrm{C}-\mathrm{NMR}\left(\mathrm{DMSO}-\mathrm{d}_{6}\right.$ ) showed two signals for the $\mathrm{COCH}_{3}$ groups at $\delta 24.1$ and $26.4 \mathrm{ppm}$, a signal at $\delta 38.6 \mathrm{ppm}$ due to $\mathrm{OCH}_{3}$ and a methylene group signal at $\delta$ $55.3 \mathrm{ppm}$.

\section{Biological Evaluation}

\section{Antimicrobial activity}

Previously untested compounds were evaluated for antimicrobial activity against eight strains of microorganisms using the agar diffusion technique. The tested compounds were screened against two Grampositive bacteria, Staphylococcus aureus (RCMB 000106) Bacillus subtilis (RCMB 000107); two Gram-negative bacteria, Pseudomonas aeruginosa (RCMB 000102), Escherichia coli (RCMB 000103) and four fungi, Aspergillus fumigatus (RCMB 002003), Geotrichum candidum (RCMB 052006), Candida albicans (RCMB 005002) and Syncephalastrum racemosum (RCMB 005003) by the disk diffusion method. Penicillin $G$. Streptomycin were used as positive control for bacterial strains while,
Itraconazole and Clotrimazole were used as positive controls for the fungi strains. The investigation of antibacterial screening data revealed that compounds $5 \mathrm{c}$ and $10 \mathrm{e}$ were the most potent towards the Grampositive bacteria S. aureus and B. subtilis. Compounds $6 \mathrm{c}, 10 \mathrm{e}$ and $11 \mathrm{~b}$ showed good to moderate activity against Gram-positive bacteria $S$. aureus and B. subtilis. Compound 2 was less potent, while $7 \mathrm{~b}, 10 \mathrm{a}$ were inactive. As for the bacterial inhibition of the Gram-negative bacteria, the screening data showed that compounds, $5 \mathrm{c}$ and $7 \mathrm{a}$ were the most potent against E. coli. Compounds 2, $6 \mathrm{c}$ and $11 \mathrm{~b}$ showed a relatively poor inhibition towards E. coli. All the tested analogs showed no activity against $P$. aeruginosa. Similarly, compounds $7 \mathrm{~b}$ and $10 \mathrm{a}, \mathrm{c}, \mathrm{e}$ were inactive against the Gram-negative bacteria P. aeruginosa or E. coli. The bacterial zone of inhibition values are given in Table 1.

Minimum inhibitory concentrations (MICs) were determined by the broth dilution technique. The nutrient broth, which contained logarithmic serially two fold diluted amounts of test compound, and controls were inoculated with approximately $5 \times 10^{5} \mathrm{c}$.f.u. $/ \mathrm{ml}$ of actively dividing bacteria cells. The cultures were incubated for $24 \mathrm{~h}$. At $37^{\circ} \mathrm{C}$ and the growth was monitored visually and spectrophotometrically. The lowest concentration (highest dilution) required to arrest the growth of bacteria was regarded as minimum inhibitory concentration (MIC). To obtain the minimum bactericidal concentration (MBC), $0.1 \mathrm{ml}$ volume was taken from each tube and spread on agar plates. The number of c.f.u. was counted after $18-24 \mathrm{~h}$ of incubation at $35^{\circ} \mathrm{C}$. $\mathrm{MBC}$ was defined as the lowest drug concentration at which $99.9 \%$ of the inoculums were killed. The minimum inhibitory concentration and minimum bactericidal concentration are given in Table 2 .

\section{Antifungal studies}

Antifungal activity testing was also done by the disk diffusion method [43]. For assaying antifungal activity Aspergillus fumigatus

\begin{tabular}{|c|c|c|c|c|}
\hline \multirow{2}{*}{ Comp. No. } & \multicolumn{4}{|c|}{ Diameter of zone of inhibition (mm) } \\
\cline { 2 - 5 } & Gram-positive bacteria & Gram-negative bacteria \\
\cline { 2 - 5 } & S. aureus & B. subtilis & P. aeruginose & E. coli \\
\hline $\mathbf{2}$ & $17.9 \pm 0.05$ & $16.1 \pm 0.01$ & NA & $10.1 \pm 0.01$ \\
\hline $\mathbf{5 c}$ & $24.0 \pm 0.01$ & $26.4 \pm 0.05$ & NA & $18.8 \pm 0.02$ \\
\hline $\mathbf{6 c}$ & $20.0 \pm 0.08$ & $19.5 \pm 0.03$ & NA & $9.8 \pm 0.06$ \\
\hline 7a & $23.4 \pm 0.01$ & $25.4 \pm 0.03$ & NA & $16.3 \pm 0.08$ \\
\hline 7b & NA & NA & NA & NA \\
\hline 10a & NA & NA & NA & NA \\
\hline 10c & NA & NA & NA & NA \\
\hline 10e & $20.4 \pm 0.08$ & $21.8 \pm 0.01$ & NA & NA \\
\hline 11b & $21.2 \pm 0.05$ & $22.8 \pm 0.09$ & NA & $9.6 \pm 0.08$ \\
\hline Standard a & $29.48 \pm 0.82$ & $32.56 \pm 0.5$ & $28.32 \pm 0.1$ & $33.56 \pm 0.07$ \\
\hline Standard b & $25.0 \pm 0.2$ & $29.0 \pm 0.04$ & $24.0 \pm 0.1$ & $25.0 \pm 0.03$ \\
\hline DMSO & -- & -- & -- & - \\
\hline
\end{tabular}

Table 1: Antibacterial activity of compounds 2, 5c, 6c, 7a,b, 10a,c,e and 11b.

\begin{tabular}{|c|c|c|c|c|c|c|c|c|}
\hline \multirow{2}{*}{$\begin{array}{c}\text { Comp. } \\
\text { No. }\end{array}$} & \multicolumn{6}{|c|}{ Diameter of zone of inhibition (mm) } \\
\cline { 2 - 9 } & \multicolumn{2}{|c|}{ Gram-positive bacteria } & \multicolumn{3}{c|}{ Gram-negative bacteria } \\
\cline { 2 - 9 } & \multicolumn{2}{|c}{ S. aureus } & \multicolumn{2}{c|}{ B. subtilis } & \multicolumn{2}{c|}{ P. aeruginose } & \multicolumn{2}{c|}{ E. coli } \\
\cline { 2 - 9 } & MIC & MBC & MIC & MBC & MIC & MBC & MIC & MBC \\
\hline \multirow{2}{*}{$\mathbf{5 c}$} & 39 & 100 & 19 & 50 & NA & $>100$ & 156 & $>100$ \\
\hline $\mathbf{6 c}$ & 78 & $>100$ & 156 & $>100$ & NA & $>100$ & 625 & $>100$ \\
\hline $\mathbf{7 a}$ & 39 & 100 & 19 & 50 & NA & $>100$ & 156 & $>100$ \\
\hline $\mathbf{1 1 b}$ & 39 & 100 & 39 & 100 & NA & $>100$ & 625 & $>100$ \\
\hline
\end{tabular}

MIC $(\mu \mathrm{g} / \mathrm{ml})=$ Minimum inhibitory concentration, that is, the lowest concentration of the compound to inhibit the growth of bacteria completely; MBC $(\mu \mathrm{g} / \mathrm{ml})=$ minimum bactericidal concentration, that is the lowest concentration of the compound for killing the bacteria completely.

Table 2: MIC and MBC results of compounds $5 c, 6 c, 7 a$ and $11 b$. 
(RCMB 002003), Geotrichum candidum (RCMB 052006), Candida albicans (RCMB 005002) and Syncephalastrum racemosum (RCMB 005003) were recultured in DMSO by the agar diffusion method. The lowest concentration (highest dilution) required to arrest the growth of fungus was regarded as minimum inhibitory concentration (MIC). The minimum inhibitory concentration and minimum fungicidal concentration are given in Table 3.

According to the results of bioactivity studies, it is noted that compounds $5 \mathrm{c}$ and $7 \mathrm{a}$, which contain the pyridine-3-carbonitrile moiety, provide better antimicrobial activity against $S$. aureus and $B$. subtilis than the other compounds $(6 \mathrm{c}, 10 \mathrm{e}, 11 \mathrm{~b})$. Surprisingly, the pyrimidine thione derivatives $(10 \mathrm{a}, \mathrm{c})$ were inactive against any Grampositive bacteria, Gram-negative bacteria or fungi. Compounds $(5 c, 6 c$, 7a) which contain 2-thioxo-3-carbonitrile pyridine moiety, 2-amino3 -carbonitrile pyridine moiety and pyridone-3-carbonitrile moiety, respectively, exhibited the best antimicrobial activity against the fungi tested.

\section{Cytotoxicity studies}

Cytotoxicity tests were performed using compounds $4,5 \mathrm{c}, 10 \mathrm{c}$ and 11c against three cancer cell lines, breast cancer cell line MCF-7, colon carcinoma cells (HCT), human epidermid/arynx carcinoma cell line (HEp2) by using a modified method [35]. The results (Tables 3 and 4) showed that 4 had slight activity toward the HCT cell line $\left(\mathrm{IC}_{50}=4.7 \mu \mathrm{g} /\right.$ $\mathrm{ml})$ and its activity towards MCF-7 cell line was lower $\left(\mathrm{IC}_{50}=2.7 \mu \mathrm{g} /\right.$ $\mathrm{mL})$. Compound 11c exhibited cytotoxic activity against the HCT cell line $\left(\mathrm{IC}_{50} 10.2 \mu \mathrm{g} / \mathrm{ml}\right)$ and a higher cytotoxic activity against MCF-7 with $\mathrm{IC}_{50}=20.7 \mu \mathrm{g} / \mathrm{ml}$. The cytotoxic activity of $5 \mathrm{c}$ towards HEP-2 was moderately potent with an $\mathrm{IC}_{50}=10.2 \mu \mathrm{g} / \mathrm{ml}$ while its cytotoxic activity against colon carcinoma cells was very low with an $\mathrm{IC}_{50}=2.1 \mu \mathrm{g} / \mathrm{ml}$. The cytotoxic activity of $10 \mathrm{c}$ towards the MCF-7 cell line was relatively weak with an $\mathrm{IC}_{50}=4.8 \mu \mathrm{g} / \mathrm{ml}$, while the cytotoxicity against $\mathrm{HCT}$ cell line was nearly inactive given the observed $\mathrm{IC}_{50}$ of $0.5 \mu \mathrm{g} / \mathrm{ml}$.

The nucleoside analogs 14,17a, 18a, and 20b (Table 5) showed cytotoxic activity against HTC and MCF-7 and Hepatocellular carcinoma cells HepG2. The $\mathrm{IC}_{50}$ of compound 14, with values 0.9 and $1.5 \mu \mathrm{g} / \mathrm{ml}$, indicates high potency against HCT and MCF-7, respectively

\begin{tabular}{|c|c|c|c|c|c|c|c|c|}
\hline \multirow{2}{*}{$\begin{array}{c}\text { Comp. } \\
\text { No. }\end{array}$} & \multicolumn{9}{|c|}{ Diameter of zone of inhibition (mm) } \\
\cline { 2 - 10 } & \multicolumn{2}{|c|}{$\boldsymbol{A F}$} & \multicolumn{2}{c|}{ GC } & \multicolumn{2}{c|}{ CA } & \multicolumn{2}{c|}{ SR } \\
\cline { 2 - 10 } & MIC & MFC & MIC & MFC & MIC & MFC & MIC & MFC \\
\hline $\mathbf{5 c}$ & 39 & 78 & 19 & 39 & 78 & 156 & 156 & 313 \\
\hline $\mathbf{6 c}$ & 39 & 78 & 39 & 78 & 156 & 313 & 313 & 625 \\
\hline $\mathbf{7 a}$ & 19 & 39 & 19 & 39 & 78 & 156 & 156 & 313 \\
\hline $\mathbf{1 1 b}$ & 39 & 78 & 78 & 156 & 156 & 313 & 313 & 625 \\
\hline
\end{tabular}

*Positive control Intraconazole and clotrimazole. AF: Aspergillus fumigatus, GC Geotrichum candidum, CA; Candida albicans, SR: Syncephalastrum racemosum. MIC $(\mu \mathrm{g} / \mathrm{ml})=$ Minimum inhibitory concentration, that is the lowest concentration of the compound to inhibit the growth of fungus completely. MFC $(\mu \mathrm{g} / \mathrm{ml})=$ Minimum fungicidal concentration, that is, the lowest concentration of the compound for killing the fungus completely.

Table 3: MIC* and MFC of compounds 5c, 6c, 7a, 11b.

\begin{tabular}{|c|c|c|c|c|}
\hline \multirow{2}{*}{ Cell lines $^{\mathbf{a}}$} & \multicolumn{4}{|c|}{$\mathbf{I C}_{\mathbf{5 0}}(\boldsymbol{\mu g} / \mathbf{m l})^{\mathbf{b}, \mathbf{c}}$} \\
\cline { 2 - 5 } & $\mathbf{4}$ & $\mathbf{5 c}$ & $\mathbf{1 0 c}$ & $\mathbf{1 1 c}$ \\
\hline MCF-7 & 2.7 & -- & 4.8 & 20.7 \\
\hline HCT & 4.7 & 2.1 & 0.5 & 10.2 \\
\hline HEp2 & -- & 10.2 & -- & -- \\
\hline
\end{tabular}

${ }^{a}$ Cancer cell lines were breast carcinoma cells (MCF-7), colon carcinoma cells (HCT), human epidermid/arynx carcinoma cell line (HEp2). ${ }^{\text {bThe }}$ assays were performed in triplicate.

Table 4: In vitro Cytotoxic activity of 4, 5c, 10c, 11c in human MCF-7, HCT, HEp2 cell lines.

\begin{tabular}{|c|c|c|c|c|}
\hline Cell lines $^{\mathbf{a}}$ & \multicolumn{4}{|c|}{$\mathbf{I C}_{\mathbf{5 0}}(\boldsymbol{\mu g} / \mathbf{m l})^{\mathbf{b}}$} \\
\hline & $\mathbf{1 4}$ & $\mathbf{1 7 a}$ & $\mathbf{1 8 a}$ & $\mathbf{2 0 b}$ \\
\hline HCT & 0.9 & NT & 19.2 & 16.7 \\
\hline MCF-7 & 1.5 & NT & 1.1 & 14.4 \\
\hline HepG2 & NT & 2 & NT & NT \\
\hline
\end{tabular}

${ }^{a}$ Cancer cell lines were colon carcinoma cells HCT, Hepatocellular, carcinoma cells HepG2, Breast carcinoma cells MCF-7; ${ }^{\text {}}$ Assays were performed in triplicate. NT indicates not tested.

Table 5: In vitro Cytotoxic activity of nucleoside analogs $14,20 \mathrm{~b}, 17 \mathrm{a}, 18 \mathrm{a}$ in human MCF-7, HCT, HEp2 cell lines.

[44,45]. The nucleoside analog 17 a exerted cytotoxic activity against $\mathrm{HepG}_{2}$ with $\mathrm{IC}_{50}=2 \mu \mathrm{g} / \mathrm{ml}$. The nucleoside analog $18 \mathrm{a}$ exerted activity against HCT with $\mathrm{IC}_{50}$ of $19.2 \mu \mathrm{g} / \mathrm{ml}$ which decreased when tested against MCF-7 to an $\mathrm{IC}_{50}=1.1 \mu \mathrm{g} / \mathrm{ml}$. The nucleoside analog $20 \mathrm{~b}$ selectively exhibited cytotoxic activity against HCT and MCF-7 cell lines with $\mathrm{IC}_{50}$ of 16.7 and $14.4 \mu \mathrm{g} / \mathrm{ml}$ respectively.

\section{Conclusion}

In summary, we have synthesized a novel series of nucleoside analogs in moderate to high yields. The prepared compounds which contain the pyridine-3-carbonitrile moiety provide better antimicrobial activity against $S$. aureus, B. subtilis than similar molecules without this functionality. Most of the prepared compounds revealed potential anticancer activity against the colon cancer cell line, Hepatocellular cancer cell line, Breast cell line and epidermis/larynx cancer cell line. Compounds 4, 5c,10c, 11c, 14, 17a, 18a and 20b exhibited good antitumor activity when compared with the reference drug.

\section{References}

1. Taguchi T, Terasawa T, Abe O, Yoshida $Y$, Tominaga $T$, et al. (1985) A comparative study of 5'-DFUR and tegafur in recurrent breast cancer. Gan To Kagaku Ryoho 12: 2052-2060.

2. Kreis W, Watanabe KA, Fox J (1978) Structural requirements for the enzymatic deamination of cytosine nucleosides. J Helv Chem Acta 61: 1011-1016.

3. Secrist JA 3rd, Tiwari KN, Riordan JM, Montgomery JA (1991) Synthesis and biological activity of 2'-deoxy-4'-thio pyrimidine nucleosides. J Med Chem 34: 2361-2366.

4. Dyson MR, Coe PL, Walker RT (1991) The synthesis and antiviral activity of some 4'-thio-2'-deoxy nucleoside analogues. J Med Chem 34: 2782-2786.

5. Tiwari KN, Secrist JA, Montgomery JA (1994) Synthesis and biological activity of $4{ }^{\prime}$-thionucleosides of 2-chloroadenine. Nucleosides Nucleotides 13: 1819.

6. Takashi JK, Motoyama M, Akashi H, Sasaki T (1994) Synthesis and antitumor activities of D-and L-2'-deoxy-4'-thiopyrimidinenucleosides. Nucleosides Nucleotides 13: 1347.

7. Yoshimura Y, Kitano K, Yamada K, Sakata S, Miura S, et al. (2000) Synthesis and biological activities of 2'-deoxy-2'-fluoro-4'-thioarabinofuranosylpyrimidine and -purine nucleosides. Bioorg Med Chem 8: 1545-1558.

8. Adamo MFA, Aadlington RM, Baldwin JE, Day AL (2004) A parallel synthesis approach towards a family of C-nucleosides. Tetrahrdron 60: 841-849.

9. Kumar RK, Davis DR (1997) Synthesis and studies on the effect of 2-thiouridine and 4-thiouridine on sugar conformation and RNA duplex stability. Nucleic Acids Res 25: 1272-1280.

10. Amr AE (2000) Ind J Heterocycl Chem 10: 49-58.

11. Amr AE, Mohamed AM, Ibrahim AAZ (2003) Synthesis of Some New Chira Tricyclic and Macrocyclic Pyridine Derivatives as Antimicrobial Agents. Naturforshc 58: 861-868.

12. Hammam AG, Fahmy AFM, Amr AE, Mohamed AM (2003) Synthesis of novel tricyclicheterocyclic compounds as potential anticancer agents using chromanone and thiochromanoneas synthons. Int J Chem 428: 1985-1993.

13. Hammam AG, Abdel Hafez NA, Midura WH, Mikolajczyk MZ (2000) Chemistry of Seven-Membered Heterocycles, VI. Synthesis of Novel Bicyclic Heterocyclic Compounds as Potential Anticancer and Anti-HIV Agents. Naturforsch 55: 417-424. 
Citation: Soliman FMA, Dawoud NTA, Hamza RM (2015) Synthesis, Biological and Anti-tumor Evaluation of Some New Nucleosides Incorporating Heterocyclic Moieties. Med chem 5: 496-504. doi: 10.4172/2161-0444.1000308

14. Hammam AG, Sharaf MA, Abdel Hafez NA (2001) Int J Chem 40B: 213-225.

15. Rashad AE, Mahmoud AE, Ali MM (2011) Synthesis and anti cancer effects of some novel Pyrazolo[3,4-d] Pyrimidine derivatives by generating reactive oxygen species in human breast adenocarcinoma cells. Eur J Med Chem 46: 1019-1026.

16. Seo TS, Li Z, Ruparel H, Ju J (2003) Click chemistry to construct fluorescent oligonucleotides for DNA sequencing. J Org Chem 68: 609-612.

17. Ikemoto NI, Schreiber SL (1992) Totol synthesis of (-)-hikizimycin employing the strategy of two directional chain synthesis. J Am Chem Soc 114: 2524 2536.

18. Maity JK, Mukherjee S, Drew MG, Achari BB, Mandal SB (2007) First example of 5/6-O-linked pseudosaccharides: synthesis of bicyclic nucleosides containing azido or extended carbohydrate moiety. Carbohydrate Res 342: 2511- 2521.

19. Tripthi S, Maity JK, Achari B, Mandal SB (2005) Bicyclic nucleoside analogues from D-glucose: Synthesis of chiral as well as racemic , 4-dioxepane ring-fused derivatives. Carbohydrate Res 340: 1081- 1087.

20. Pérez N, Gordillo B (2003) Rapid synthesis of ( \pm )-r-7-benzyloxy methylCyclopenta-Cis-[4,5][,3]-oxazolo [3,2-a] Pyrimidinones versatile carbocyclic nucleoside Precursors. Tetrahedron 59: 671- 676.

21. Nguyen-Ba N, Brown WL, Chan L, Lee N, Brasilli L, et al. (1999) Synthesis and anti-HIV activity of ,3 dithiolane nucleosides. Chem Commun 1245-1246.

22. Hanrahan JR, Hutchinson DW (1992) The enzymatic synthesis of antiviral agents. J Biotechnol 23: 193-210.

23. Shira $H$, Yokozeki $K$ (1988) Enzymatic production of ribavirin from purine nucleosides by Brevibacterium acetylicum ATCC954. Agric Biol Chem 52: 1777- 1783.

24. Wei XK, Ding QB, Zhang L, Guo YL, Ou L, et al. (2008) Induction of nucleoside phosphorylase in Enterobacter aerogenes and enzymatic synthesis of adenine arabinoside. J Zhejiang Univ Sci B 9: 520-526.

25. Shirae H, Kobayashi K, Shiragami H, Irie Y, Yasuda N, et al. (1989) Production of 2',3'-dideoxyadenosine and 2',3'-dideoxyinosine from 2',3'-dideoxyuridine and the corresponding purine bases by resting cells of Escherichia coli AJ 2595. Appl Environ Microbiol 55: 419-424.

26. Holm berg K (2001) Natural surfactants. Curr Opin Colloid Interface Sci 6: 148-159.

27. Stubenrauch C (2001) Sugar surfactants-aggregation, interfacial, and adsorption phenomena. Curr Opin Colloid Interface Sci 6: 160-170.

28. Hollingsworth RI, Wang G (2000) Toward a carbohydrate-based chemistry: progress in the development of general-purpose chiral synthons from carbohydrates. Chem Rev 100: 4267-4282.

29. Iglesias-Guerra F, Romero I, Alcudia F, Vega-Perez JM (1998) Alkylating agents from sugars. Cyclophosphamides derived from 2-amino-2-deoxy-dallose. Carbohydr Res 308: 57-62.
30. Iglesias-Guerra F, Candela JI, Bautista J, Alcudia F, Vega-Perez JM (1999) Alkylating agents from sugars. Alkyl hexopyranoside derivatives as carrier systems for chlorambucil. Carbohydr Res 316: 71-84.

31. Jelinek R, Kolusheva S (2004) Carbohydrate biosensors. Chem Rev 104 5987-6015.

32. Tatsuta K, Hosokawa S (2005) Total synthesis of selected bioactive natural products: illustration of strategy and design. Chem Rev 105: 4707-4729.

33. Trivedi R, Reddy ER, Kumar KCh, Sridhan B, Kumar KP, et al. (2011) Efficient Synthesis, Structural Characterization and antimicrobial activity of chiral aryl boronate esters of 2-O- isopropylidene-a-D-xylofuranose. Bioorg \& Med Chem Lett 21: 3890-3893.

34. Palleros RD (2004) Solvent-Free Synthesis of Chalcones. J Chem Educ 81: 1345.

35. Zhong-Liang G, Liang-Wen Z, Bao-Xiang Z, De-Zhong Y, Hong-Shui L, et al (2010) The synthesis, X-ray crystal structure and optical properties of novel ,3,5-triaryl pyrazoline derivatives. J Photochem Photobid A: Chem 209: 49-55.

36. Ismail ZH, Soliman FMA, Abdelmonem SH (2011) Synthesis, antimicrobial and antitumor activity of some 3,5-diaryl-and ,3,5-triaryl-2-pyrazoline derivatives. J Amer Sci 7: 756-767.

37. Saleh RM, Soliman AY, Soliman FMA (1991) Some reaction of chalcone epoxides. Rev Roum Chem 36: 1337-1343.

38. Sammour A, Selim MI, Hataba AM (1972) Synthesis Elaboration on Chalcone and its derivatives. Egypt J Chem 15: 531.

39. El-Kady M, El-Hashash MA, Mohamed MM (1978) Egypt J Chem 21: 455-463.

40. Abdalla M, Salem MA, Hataba AM (1979) Egypt J Chem 22: 443-445.

41. Cekaviciute M, Simokaitiene J, Grazulevicius JV, Buika G, Jankauskas V (2011) Dyes and Pigments 92: 654-658.

42. Rosenquist A, Kvarnstrom I, Classon B, Samuelsson B (1996) Synthesis of Enantiomerically Pure Bis(hydroxymethyl)-Branched Cyclohexenyl and Cyclohexyl Purines as Potential Inhibitors of HIV. J Org Chem 61: 6282-6288.

43. Tengchaisri T, Chawengkirttikul R, Rachaphaew N, Reutrakul V, Sangsuwan $\mathrm{R}$, et al. (1998) Antitumor activity of triptolide against cholangiocarcinoma growth in vitro and in hamsters. Cancer Lett 133: 169-175.

44. Sampson PB, Liu Y, Forrest B, Cumming G, Li SW, et al. (2015) The discovery of Polo-like kinase 4 inhibitors: identification of $(1 \mathrm{R}, 2 \mathrm{~S}) .2-(3-$ ((E).4-(((cis).2,6-dimethylmorpholino)methyl)styryl). 1H.indazol-6-yl)-5'methoxyspiro[cyclopropane-1,3'-indolin]-2'-one (CFI-400945) as a potent, orally active antitumor agent. J Med Chem 58: 147-169.

45. Yu B, Yu Z, Qi PP, Yu DQ, Liu HM (2015) Discovery of orally active anticancer candidate $\mathrm{CFI}-400945$ derived from biologically promising spirooxindoles: Success and challenges. Eur J Med Chem 95: 35-40. 